\title{
Inter-hospital obstetric referrals: public versus private sector to a tertiary care teaching hospital in South Kerala, India
}

\author{
Heera Shenoy T. ${ }^{1 *}$, Sheela Shenoy ${ }^{2}$
}

\begin{abstract}
${ }^{1}$ Department of Obstetrics and Gynecology, Travancore Medical College Hospital, Kollam, Kerala, India
${ }^{2}$ Department of Obstetrics and Gynecology, Sri Avittom Tirunal Hospital, Thiruvananthapuram, Kerala, India
\end{abstract}

Received: 29 November 2018

Accepted: 04 December 2018

*Correspondence:

Dr. Heera Shenoy T.,

E-mail: heerarprabhu@gmail.com

Copyright: (c) the author(s), publisher and licensee Medip Academy. This is an open-access article distributed under the terms of the Creative Commons Attribution Non-Commercial License, which permits unrestricted non-commercial use, distribution, and reproduction in any medium, provided the original work is properly cited.

\section{ABSTRACT}

Background: Inter-hospital Emergency obstetric transfers should be carried out effectively and efficiently to avoid maternal and fetal morbidity and mortality. Authors would like to analyse the determinants ,patterns and reasons for referrals to tertiary hospital for women with obstetric high-risk, complications and obstetric emergencies from both public and private sectors and look into course in hospital and their feto-matermal morbidities.

Methods: Descriptive study done at a tertiary care teaching hospital where 124 obstetrical referrals from nearby private and public health sectors were recruited.

Results: Infertility treated obstetric referrals were at significant risk of referral ( $p$ value-0.002). Public sector referrals had past history of early pregnancy loss which was significant ( $p$ value-0.002). Public sector had statistically significant in -labour referrals ( $\mathrm{p}$ value-0.04). All the obstetric referrals from public health sector reached within half an hour while one third of private sector referrals travelled more than an hour for emergency obstetric care ( $p$ value 0.001). Bronchial Asthma caused significant morbidity among public sector referrals ( $\mathrm{p}$ value-0.001). Public sector referrals $<31$ weeks were nil while $55 \%$ obstetric referrals were referred $<31$ weeks from various private hospitals seeked neonatal care with significant $\mathrm{p}$ value (0.016). NICU admissions were statistically significant in private sector referrals (p-value 0.001). Mean hospital stay in private sector referrals was 10.17 days and it was 7.62 days in government referrals.

Conclusions: Specific guidelines for whom to refer, how to refer, when to refer and where to refer would be helpful in making timely referral. More stringent documentation in the referral slips and more co-ordination between the referral unit and the higher centers are required to build a strong health system.

Keywords: Inter-hospital, Kerala, Obstetric, Private, Public, Referral

\section{INTRODUCTION}

Inter-hospital emergency obstetric transfers should be carried out effectively and efficiently to avoid maternal and fetal morbidity and mortality. WHO has launched recommendations for antenatal care and for positive pregnancy care which emphasise appropriate maternal and foetal assessment during antenatal care, timely identification of medical or obstetric complications and high-risk pregnancies, and provision of appropriate treatment and referral. ${ }^{1}$ For this there has to be an efficient appropriate referral system which if not followed can lead to unnecessary referrals and can increase the workload on tertiary hospitals thereby causing discomfort to antenatal women and their relatives. Safe motherhood initiative acknowledges the fact of antenatal referrals by stating that a minimum of $15 \%$ of all pregnant women should deliver in obstetric 
referral facilities. ${ }^{2}$ An institution referral is when a pregnant woman seeks care at a lower level health facility (basic emergency obstetric care) and is referred onwards to a higher-level health facility (comprehensive emergency obstetric care). Referral institutions should provide a reasonable level of quality care. Referral is especially important within obstetrics due to the high numbers of professionals who support a woman through pregnancy and birth, the speed with which action often needs to be taken and the global burden of maternal mortality. $^{3}$

Delays in accessing emergency obstetric care, including poor referral systems, contribute to an increase in maternal mortality and morbidity. ${ }^{4}$ Well-established operational referral system is an essential component of strong health care system and is reflected in emergency obstetric care (EmOC) which is an indicator of an efficiently functioning health system. ${ }^{5}$ Prompt unmet obstetric needs can be better monitored if primary, secondary and tertiary levels of health care are linked through an established communication transport system. ${ }^{6}$ Obstetric complications have a different spectrum and urgency for referral. A woman with a high-risk pregnancy may require referral for further antenatal care or delivery, an early complication in pregnancy may require referral on urgent basis (within 2-3 days), and an emergency complication will require immediate transfer. Each of the complication states will also require different referral pathways.

India has a national public health sector which provides free care, and a prominent private sector which charges for services and is largely unregulated. In urban areas, cities have urban health centres and urban health posts for preventive and primary level curative care. But largely the urban population depends on public tertiary level institutions or the private sector for health care. India has a maternal mortality ratio (MMR) of 162 deaths per 100,000 live births and accounts for $17 \%$ of global maternal deaths. ${ }^{7}$

Kerala is a high-performing Indian state with regards to health indicators, with an MMR of 31 per 100,000, an institutional delivery rate of $99 \%$ and almost universal antenatal care (ANC). ${ }^{8}$ Kerala has a $94 \%$ literacy rate and over $90 \%$ of houses having electricity and a toilet facility. ${ }^{9}$ Hence, studies regarding healthcare in Kerala is likely to represent the best-case scenario within India. Even though state of Kerala has state of art health care, limited studies have been conducted to analyse referral patterns and differences in referral between public and private hospitals their outcomes and morbidities in both mother and fetus. The sixth review of NRHM10 estimated that only $22 \%$ of out-patients and $64 \%$ of inpatients visited public sector facilities.

In this study, authors have selected those cases which have been referred to a tertiary care centre in South Kerala and analysed determinants, reasons of referral, medical co-morbidities, gestational age at referral, decision-delivery delay, outcomes of mother, near misses and perinatal morbidities and documentation of referral slips.

The aims and objectives of this study are to analyse the determinants and reasons of referrals to tertiary care hospital for women with obstetric high-risk, complications, or obstetric emergencies from different sectors -Public and private sector; to look into the referral characteristics-sociodemographic, reproductive and medical comorbidities in both public and private sector obstetric referrals and to know the clinical course, maternal and neonatal morbidities in public versus private obstetric referrals.

\section{METHODS}

An observational study was conducted at a tertiary care hospital in Kerala. The sample population consisted of 124 obstetric referrals of gestation 24 weeks or more. They were grouped into public and private sector referrals All booked cases and obstetric referrals of less than 24 weeks and 6 out referrals were excluded from the study. The cases were grouped into public and private hospital referral group.

Study protocol was approved by the ethical committee. Using a pre-structured designed questionnaire, socio demographic details, medical co morbidities, indications for referral-maternal and fetal were obtained. Referral slips were analysed and documentation patterns were sought. Patients referred while in labor was noted. Gestational age at referral and gestational age at delivery was asked and decision-delivery delay was noted.

Emergency and elective case referrals were sorted. Intra partum variables and surgical morbidities were evaluated. Need for ventilation and multi-disciplinary team work, neonatal survivors versus non-survivors, term versus preterm birth, weight of babies, need for NICU admission, period of NICU stay, management in NICU and neonatal morbidities were noted in both the groups.

\section{Statistical analysis}

Data was analysed for descriptive statistics such as mean, standard deviation and percentages were computed using SPSS for Windows version 20. $\mathrm{P}$ value-<0.05 was significant.

\section{RESULTS}

The study population had 21 public sector and 103 private sector referrals. The socio-demographic data, maternal age, domicile, religion, maternal education and employment during pregnancy was comparable between these two groups. Private referrals had better monthly income than public sector (Table 1). 
Table 1: Socio-demographic profile of public and private sector referrals.

\begin{tabular}{|c|c|c|c|}
\hline Variables & Public & Private & P-value \\
\hline \multicolumn{4}{|l|}{ Age (years) } \\
\hline$<19$ & $3(14)$ & $5(4.9)$ & 0.226 \\
\hline $20-29$ & $15(72)$ & $87(85)$ & \\
\hline$>30$ & $3(14)$ & $11(10.1)$ & \\
\hline \multicolumn{4}{|l|}{ Domicile } \\
\hline Rural & $18(86)$ & $84(82)$ & 0.649 \\
\hline Urban & $03(14)$ & $19(18)$ & \\
\hline \multicolumn{4}{|l|}{$\begin{array}{l}\text { Monthly income of } \\
\text { family (Rs) }\end{array}$} \\
\hline$<10000$ & $3(14)$ & $7(6.8)$ & 0.604 \\
\hline $10000-20000$ & $11(52)$ & $37(36)$ & \\
\hline$>20000$ & $07(34)$ & $59(57.2)$ & \\
\hline \multicolumn{4}{|l|}{$\begin{array}{l}\text { Number of adults in } \\
\text { house (excluding } \\
\text { participant)/ Family }\end{array}$} \\
\hline $1-2$ (nuclear) & 0 & $02(1.4)$ & 0.115 \\
\hline $\begin{array}{l}3-4 \text { (extended } \\
\text { nuclear) }\end{array}$ & $18(86)$ & $87(85)$ & \\
\hline $5-6$ (joint) & $03(14)$ & $14(13.6)$ & \\
\hline \multicolumn{4}{|l|}{$\begin{array}{l}\text { Employed during } \\
\text { pregnancy }\end{array}$} \\
\hline No & $16(76.2)$ & $76(73.8)$ & 0.811 \\
\hline Yes & $5(23.8)$ & $27(26.2)$ & \\
\hline \multicolumn{4}{|l|}{$\begin{array}{l}\text { Highest level of } \\
\text { education }\end{array}$} \\
\hline $\begin{array}{l}\text { Completed } \\
\text { secondary school }\end{array}$ & $06(28.5)$ & $16(15)$ & 0.817 \\
\hline $\begin{array}{l}\text { Higher secondary } \\
\text { school/ Vocational } \\
\text { training }\end{array}$ & $07(33)$ & $53(52)$ & \\
\hline Graduate & $08(38.5)$ & $34(33)$ & \\
\hline
\end{tabular}

Table 2: Marital and reproductive career of public sector and private obstetric referrals.

\begin{tabular}{|c|c|c|c|}
\hline Variable & $\begin{array}{l}\text { Public } \\
n=21\end{array}$ & $\begin{array}{l}\text { Private } \\
n=103\end{array}$ & P-value \\
\hline \multicolumn{4}{|c|}{ Married life in years } \\
\hline$<2$ years & $5(24)$ & $26(25)$ & \multirow{3}{*}{0.217} \\
\hline $2-4$ years & $10(48)$ & $30(29)$ & \\
\hline$>4$ years & $6(28)$ & $47(46)$ & \\
\hline \multicolumn{4}{|l|}{ Infertility Treated } \\
\hline Yes & $6(28)$ & $22(21)$ & \multirow{2}{*}{0.002} \\
\hline No & $15(82)$ & $81(79)$ & \\
\hline \multicolumn{4}{|l|}{ Abortion-past H/o } \\
\hline Yes & $6(28)$ & $20(20)$ & \multirow{2}{*}{0.002} \\
\hline No & $15(82)$ & $80(80)$ & \\
\hline Previous delivery & $\mathrm{n}=10$ & $\mathrm{n}=49$ & \multirow{3}{*}{0.314} \\
\hline Normal delivery & $4(40)$ & $12(24)$ & \\
\hline Caesarean & $6(60)$ & $37(76)$ & \\
\hline \multicolumn{4}{|l|}{ Children in house } \\
\hline 0 & $11(52)$ & $54(52)$ & \multirow{3}{*}{0.992} \\
\hline $1-2$ & $8(38)$ & $40(38)$ & \\
\hline $3-4$ & $2(10)$ & $9(10)$ & \\
\hline
\end{tabular}

Infertility treated obstetric referrals were at significant risk of referral ( $\mathrm{p}$ value-0.002).

Public sector referrals had past history of early pregnancy loss which was significant ( $\mathrm{p}$ value-0.002) (Table 2).

Public sector had statistically significant in-labour referrals ( $\mathrm{p}$ value-0.04). All the obstetric referrals from public health sector reached within half an hour while one third of private sector referrals travelled more than an hour for emergency obstetric care ( $\mathrm{p}$ value 0.001) (Table $3)$.

Table 3: Status at referral and distance travelled for care from hospital of referral.

\begin{tabular}{|l|l|l|l|}
\hline Variable & \multicolumn{1}{c}{$\begin{array}{c}\text { Public } \\
\text { n=21 }\end{array}$} & $\begin{array}{l}\text { Private } \\
\text { n=103 }\end{array}$ & P-value \\
\hline Referral Status & Public & Private & \\
\hline In labour & $14(66)$ & $46(45)$ & 0.065 \\
\hline Not in labour & $07(34)$ & $57(55)$ & \\
\hline \multicolumn{2}{|l|}{ Time taken to reach tertiary care centre } & \\
\hline Within half an hour & $21(100)$ & $69(67)$ & 0.001 \\
\hline > Half an hour & 0 & $34(33)$ & \\
\hline
\end{tabular}

Asthma was significant morbidity for public sector referrals ( $\mathrm{p}$ value-0.001) (Figure 1).

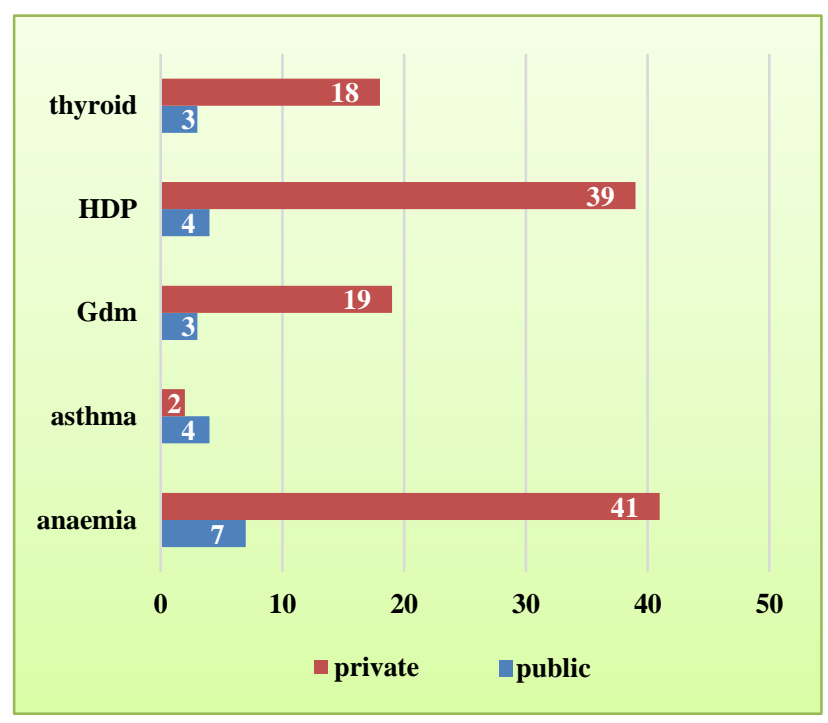

Figure 1: Medical conditions complicating obstetric referrals.

Maternal reasons predominated public sector referrals while fetal causes dominated private referrals ( $\mathrm{P}$ value 0.05). Many patients had multiple complications at the time of referral (Table 4).

Authors had $72 \%$ emergency referrals. There were no referrals from public sector $<31$ weeks while $55 \%$ were referred <31 weeks from private hospitals for neonatal care with significant $\mathrm{p}$ value (0.016) (Table 5). 
Table 4: Maternal and fetal reasons for referral in public and private obstetric cases.

\begin{tabular}{|l|l|l|}
\hline Reasons for referral & $\begin{array}{l}\text { Public } \\
\mathbf{n = 2 1}\end{array}$ & $\begin{array}{l}\text { Private } \\
\mathbf{n}=103\end{array}$ \\
\hline Maternal & $\mathbf{( \% = 7 6 )}$ & $\mathbf{( \% = 5 8 )}$ \\
\hline $\begin{array}{l}\text { Previous caesarean in } \\
\text { labour }\end{array}$ & 03 & 08 \\
\hline Preterm labour & 03 & 10 \\
\hline $\begin{array}{l}\text { Severe pre-eclampsia } \\
\text { eclampsia }\end{array}$ & 02 & 08 \\
\hline Multifetal gestation & 02 & 11 \\
\hline APH-abruptio/ praevia & 02 & 06 \\
\hline Malpresentation & 02 & 02 \\
\hline CPD/ failed induction & 01 & 03 \\
\hline PPROM & 02 & 12 \\
\hline Fetal & $\mathbf{( \% = 1 4 )}$ & $\mathbf{( \% = 4 2 )}$ \\
\hline FGR-oligamnios & 01 & 13 \\
\hline Doppler abnormality & - & 10 \\
\hline Intra -uterine demise & 01 & 05 \\
\hline Fetal distress NRFHR & 01 & 08 \\
\hline Others & 01 & 07 \\
\hline & P-value-0.05 & \\
\hline Others includ Rh negative, & prigrava in & \\
\hline
\end{tabular}

Others include $\mathrm{Rh}$ negative, short primigravida in public group and 2 cases of dengue fever, 2 cases of Chicken pox, 2 cases of $\mathrm{HbSAg}$ positive and a case of facial nerve palsy-acute episode in the private sector group.

Table 5: Gestational age at referral and timing of delivery in both groups.

\begin{tabular}{|l|l|l|l|}
\hline $\begin{array}{l}\text { GA at the time } \\
\text { of referral } \\
\text { (weeks) }\end{array}$ & $\begin{array}{l}\text { Government } \\
\text { n=21 }\end{array}$ & $\begin{array}{l}\text { Private } \\
\text { n=103 }\end{array}$ & $\begin{array}{l}\text { P- } \\
\text { value }\end{array}$ \\
\hline $24-30.6$ & - & $25(24.3)$ & 0.016 \\
\hline $31-33.6$ & $06(28.5)$ & $32(31)$ & \\
\hline $34-35.6$ & $06(28.5)$ & $28(27.2)$ & \\
\hline $36-40$ & $09(43)$ & $18(17.5)$ & \\
\hline $\begin{array}{l}\text { GA at decision/ } \\
\text { delivery (weeks) }\end{array}$ & - & & \\
\hline 24-30.6 & $06(28.5)$ & $28(27.2)$ & \\
\hline $31-33.6$ & $04(19)$ & $26(25.3)$ & \\
\hline $34-36.6$ & $11(52.5)$ & $29(28.1)$ & \\
\hline $36-40$ & & & \\
\hline $\begin{array}{l}\text { Referral } \\
\text { emergency/ } \\
\text { Elective }\end{array}$ & $15(71.5)$ & $75(72.8)$ & 0.89 \\
\hline Emergency & $06(28.5)$ & $28(27.2)$ & \\
\hline Elective & & & \\
\hline & & & \\
\hline
\end{tabular}

Caesarean section accounted for $83 \%$ of referrals. Previous caesareans (obstetric historical risk) and highrisk obstetric referrals accounted for the bulk (Figure 2).

Ten cases needed blood transfusion. 12 cases were given Magsulf regime for impending eclampsia/ eclampsia/ severe preeclampsia. There were 2 cases of Posterior
Reversible Encephalopathy Syndrome. All the 7 mothers who needed ventilator support not related to anesthesia were from private sector (Figure 3 ).

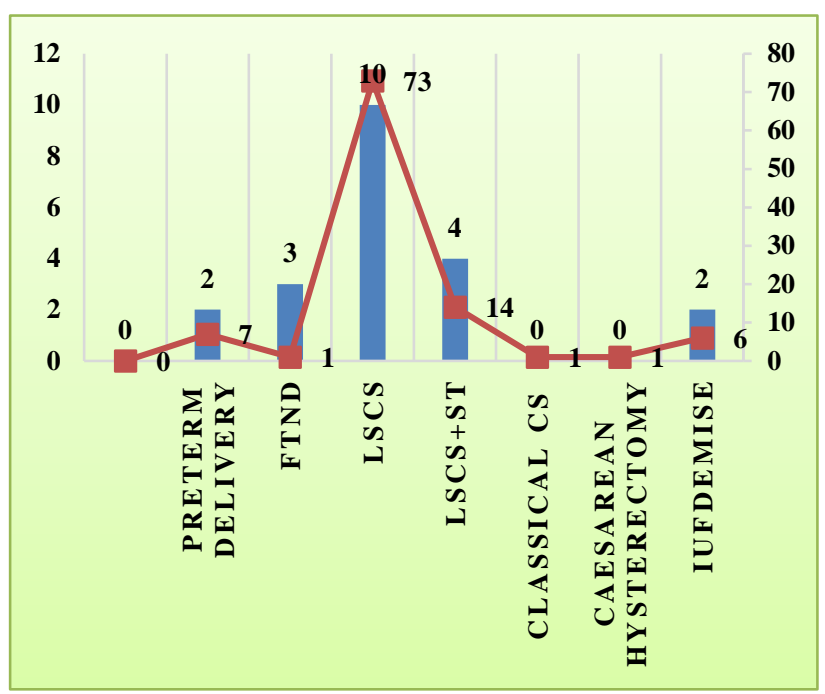

Figure 2: Outcomes of referral in both groups.

16 out of 17 babies $<1 \mathrm{~kg}$ were born to private referrals. $55 \%$ babies weighed 1500-1999g (Table 6).

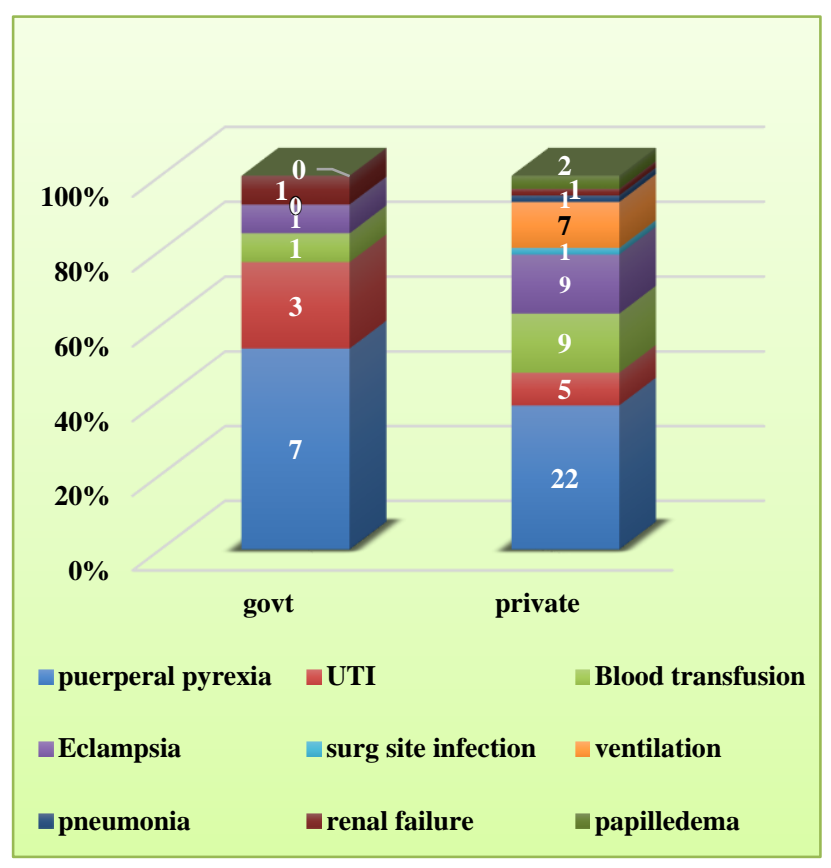

Figure 3: Morbidities of referral in both groups.

NICU admissions were statistically significant in private sector referrals ( $p$-value 0.001 ) due to preterm referrals and very low-birth weight babies. As the public sector referral babies were near term, shorter NICU stay $(<6$ days) $83 \%$ making $\mathrm{p}$ value statistically significant ( $\mathrm{p}$ value 0.007$)$. Need to resuscitate by ventilator was $71 \%$ in private sector and $50 \%$ in public sector referrals ( $\mathrm{p}$ value 0.020) (Table 7). 
Table 6: Comparison of birth weights of babies born to public versus private.

\begin{tabular}{|l|l|l|}
\hline Birth weight $(\mathrm{kg})$ & Public & Private \\
\hline$<1.000 \mathrm{~kg}$ & $1(4.1)$ & $16(13.55)$ \\
\hline $1.000-1.499 \mathrm{~kg}$ & $3(14.5)$ & $27(22.88)$ \\
\hline $1.500-1.999 \mathrm{~kg}$ & $7(30.5)$ & $28(23.73)$ \\
\hline $2.000-2.499 \mathrm{~kg}$ & $4(17.3)$ & $23(19.49)$ \\
\hline $2.500-2.999 \mathrm{~kg}$ & $4(17.3)$ & $12(10.17)$ \\
\hline $3.000-3.499 \mathrm{~kg}$ & $4(17.3)$ & $10(8.48)$ \\
\hline$>3.500 \mathrm{~kg}$ & 0 & $2(1.69)$ \\
\hline Total & 23 & 118 \\
\hline
\end{tabular}

Table 7: Neonatal morbidity among public versus private obstetric referrals.

\begin{tabular}{|c|c|c|c|}
\hline & Public & Private & $\begin{array}{l}\text { P- } \\
\text { value }\end{array}$ \\
\hline \multicolumn{4}{|l|}{$\begin{array}{l}\text { Total neonates } \\
(n=141)\end{array}$} \\
\hline Survivors & 21 & 90 & \multirow[t]{3}{*}{-} \\
\hline Non -survivors & 2 & 22 & \\
\hline IUF Demise & 2 & 4 & \\
\hline Admission to NICU & $\mathrm{n}=\mathbf{2 3}$ & $\mathrm{n}=\mathbf{1 1 2}$ & \\
\hline Yes & $12(52.17)$ & $84(75)$ & \multirow{2}{*}{0.001} \\
\hline No & $11(47.83)$ & $18(25)$ & \\
\hline $\begin{array}{l}\text { Days in NICU } \\
(n=96)\end{array}$ & $n=12$ & $n=84$ & \\
\hline$<2$ days & $4(33.3)$ & $12(14.3)$ & \multirow{3}{*}{0.007} \\
\hline 3 - 6 days & $6(50)$ & $18(21.4)$ & \\
\hline$>6$ days & $2(16.7)$ & $54(64.3)$ & \\
\hline Patient in NICU & $\mathrm{n}=12$ & $n=84$ & \multirow{4}{*}{0.020} \\
\hline Ventilator & $6(50)$ & $60(71.4)$ & \\
\hline CPAP & $6(50)$ & $14(16.6)$ & \\
\hline Phototherapy & 0 & $10(12)$ & \\
\hline $\begin{array}{l}\text { Mean NICU stay in } \\
\text { days-government } \\
\text { referrals }\end{array}$ & \multicolumn{2}{|l|}{7.62} & \\
\hline $\begin{array}{l}\text { Mean NICU stay in } \\
\text { days-private } \\
\text { referrals }\end{array}$ & \multicolumn{2}{|l|}{10.17} & \\
\hline
\end{tabular}

In present study, $70 \%$ of private sector referrals had structured letters and $28 \%$ had unstructured ones and $2 \%$ had no document available at referral while documentation was slightly better in the public sector (Table 8).

Table 8: Document handed over to the in-referral centre.

\begin{tabular}{|l|l|l|}
\hline Referral letter & $\begin{array}{l}\text { Public } \\
\mathbf{n = 2 1}\end{array}$ & $\begin{array}{l}\text { Private } \\
\mathbf{n}=\mathbf{1 0 3}\end{array}$ \\
\hline Structured & 17 & 72 \\
\hline Unstructured & 3 & 29 \\
\hline No document available & 1 & 2 \\
\hline Medical, obstetric details, scan & $\mathbf{n = 2 1}$ & $\mathbf{n = 1 0 3}$ \\
\hline Available & 16 & 67 \\
\hline Not available & 5 & 36 \\
\hline
\end{tabular}

\section{DISCUSSION}

In present descriptive study there were 1600 deliveries which constituted 131 in-referrals and 7 out-referrals which in present study is $8 \%$ similar to $9.4 \%$ in Chaturvedi. ${ }^{11}$ The proportion of in-referrals was highest in government tertiary institutions $(21.2 \%)$ followed by private hospitals $(16.1 \%)$ in contrast to $16.9 \%$ and $83.1 \%$ in public and private hospitals respectively. $73.4 \%$ were in the age group of 20-30 years as in Morsheda et al. ${ }^{12}$ $82.3 \%$ were from the rural area in this and also in Vinayak et al and Wahane et al that reported $77 \% .^{13,14}$ This high proportion of rural population may be due to delay in access to health care and lack of awareness and poor transport facilities. Infertility treated obstetric referrals were at significant risk of referral ( $p$ value0.002). Public sector referrals had past history of early pregnancy loss which was significant ( $p$ value-0.002). Public sector had statistically significant in-labour referrals ( $p$ value-0.04) in contrast to inter-hospital transfers in Brunei where antenatal referrals constituted the majority. ${ }^{15}$ All the obstetric referrals from public health sector reached within half an hour while one third of private sector referrals travelled more than an hour for emergency obstetric care ( $p$ value 0.001) similar to Brunei study but in contrast to Sheik et al. ${ }^{16}$ The high proportion of referrals and the experience faced during the same are probably a reason why pregnant women in India chose to deliver at private institutions to avoid transfers. ${ }^{17}$ In present institution where annual delivery rates are around 700 cases and 52 cases were referred per year authors had $16.9 \%$ public and $83.1 \%$ private sector referrals. Tanzanian study reported that $28 \%$ of women registered for ANC at peripheral health centre were referred to higher level hospitals including private tertiary care teaching hospitals. ${ }^{18}$

Referral is a component of high-quality obstetric care and good communication depends on knowledge, skills and practices of obstetricians and inter-facility relationships. Referral letter reflects the diagnostic skills, communication skills and professionalism of the doctor. The RCH guidelines recommend that health staff should provide a brief referral note, and if possible, inform the higher-level facility, mostly they just give verbal instructions to the family of the patient. ${ }^{19}$ Usually no records relating to referrals between institutions are kept and no referral slips or communication about the referred case is provided to the next level institution. There is no routine feedback mechanism or routine monitoring of the appropriateness of referrals in India. Maitra, and Barua, noted that there were no referral records for identifying high-risk pregnancies before the intervention was implemented. ${ }^{20,21}$ Grimshaw et al, reported that only structured referral sheets and involvement of consultants in educational activities would improve the effectiveness and efficiency of referrals from primary care to secondary care, following Cochrane data base review. ${ }^{22}$ The lack of a referral letter or a poor quality referral letter can compromise management of a patient. ${ }^{22}$ In present study, 
$70 \%$ of private sector referrals had structured letters and $28 \%$ had unstructured ones and $2 \%$ had no document available at referral while documentation was slightly better in the public sector. Ohn et al had $19.4 \%$ referrals with no referral slips. ${ }^{15}$ In Chaturvedi et al study and Madhya Pradesh study, $72 \%$ in-referred cases had a referral slip however they mostly did not contain the reasons for referral and the treatment provided before referral. ${ }^{11,23}$ As studied by Alehgen, referrals were to be made to the next level of available public health institution or to a private health institution or if they complied with the choice of suggested referral institution. ${ }^{24}$ Authors observed that $76 \%$ public sector referrals had obstetric scans and antenatal card with them while $35 \%$ of private care seekers had no sonogram or antenatal card making treatment expensive and unnecessary phase 2 delay. Interventions of formalised patient held records are supported by the World Health Organisation to improve the quality and utilisation of antenatal care. ${ }^{1}$ According to Sheikh et al, $86 \%$ of participants thought that receiving documents such as referral letters was important; mostly because it helped them understand their condition and explain it to others. ${ }^{16}$ Women generally recognised the importance of information transfer and of receiving documentation from their healthcare providers.

Pre-eclampsia was detected in $11 \%$ and severe anaemia in $8 \%$ of all pregnant women in the study by Alehgen in 2012. ${ }^{24}$ Anaemia was prevalent in $38.7 \%$ in this study comparing to Rathi et al $46 \% .^{25}$ Institutions providing obstetric care should have back up of blood bank. Patel et al noted that HDP was $16 \%$ and it was higher, $33.06 \%$ in this study. ${ }^{26}$ Asthma was significant morbidity among public sector referrals ( $\mathrm{p}$ value-0.001) as in Ohn et al. ${ }^{15} \mathrm{~A}$ study conducted in Tanzania reported that among $28 \%$ of referred patients, $70 \%$ were referred due to demographic risks, $12 \%$ due to obstetric historical risks, $12 \%$ prenatal and $5.5 \%$ intrapartum and postpartum risks. Jahn and De Brouwere identified a core set of indications for referral which would produce referral rates of $6 \%$ to $10 \%$ and reduce a lot of un-necessary high-risk referrals mainly previous caesarean section (obstetric historical risk), breech presentation, transverse lie, multiple gestation, hypertension, and severe anaemia. Maternal referrals included previous Caesarean in labor, preterm labour, severe preeclampsia, multi-fetal gestation. $27.6 \%$ referrals were for hypertensive disorders and $34.5 \%$ were for preterm labor in the study by Agarwal et al. ${ }^{27}$ There were 2 chronic HBV infections similar to Agarwal et al. ${ }^{27}$ Infections included 4 dengue fever cases, 2 cases of chickenpox in labour in private referrals. Emergency intervention was needed for severe preeclampsia, eclampsia, previous cesarean in labour, antepartum haemorrhage preterm labour and higher order pregnancies remote from term. Agarwal et al, reported 16 patients with eclampsia, a major preventable cause of maternal mortality. Most of the patients $42 \%$ in private and $14 \%$ in public were referred for better neonatal care either due to anticipated preterm birth, fetal growth restriction, oligamnios, fetal distress, Doppler abnormality had to be managed with emergency caesarean delivery. In-referrals in Rajasthan had reasons such as obstructed labour (25\%), antepartum haemorrhage $(16 \%)$, pregnancy induced hypertension $(16 \%)$, severe anaemia (14\%), complicated abortion $(12 \%)$, post-partum haemorrhage $(6 \%)$ and twin pregnancy $(6 \%) .^{28}$

Authors had seven out-referrals (5.6\%), two cases of complete placenta praevia from public sector and five cases from private sector (Scrub typhus, Swine flu, Autoimmune Thrombocytopenia, Hepatitis A, PPROM). Chaturvedi reported that $5.9 \%$ women seeking delivery care were referred out. ${ }^{11}$ The out-referral rate was highest from PHCs $(14 \%)$ followed by $\mathrm{CHCs}(8 \%)$ and tertiary hospitals $(1 \%)$. Half of the referrals from PHC were directly to tertiary hospitals, bypassing the CHCs. There were $11 \%$ "near-miss" cases in Kaul et al and 4 nearmiss" $(3.22 \%)$ referrals from present private sector needing multidisciplinary care. ${ }^{29}$

Kirti et al in a similar study had $34 \%$ referrals from state general hospitals and $27 \%$ rural hospitals while $9 \%$ were only from private hospitals. ${ }^{30}$ In contrast to ours where $83 \%$ from private hospitals There were no referrals from public sector $<31$ weeks while $55 \%$ were referred $<31$ weeks from private hospitals for neonatal care with significant $\mathrm{p}$ value (0.016). $43 \%$ of these preterm were delivered by emergency caesareans $<34$ weeks while $52 \%$ of public sector babies were born $>36$ weeks. 16 out of 17 babies $<1 \mathrm{~kg}$ were born to private referrals. $55 \%$ babies weighed 1500-1999g.

Caesarean section accounted for outcome of $83 \%$ of referrals. Previous caesareans (obstetric historical risk) and high-risk obstetric referrals accounted for the bulk. The rate of caesarean deliveries in the private sector is extremely high $(70 \%)$ and more than twice that in the public sector in Brazil as many Brazilian obstetricians believe that a caesarean section is actually safer for the newborn and more comfortable than a vaginal delivery for most high risk women. ${ }^{31}$ Ambreen et al had $62 \%$ cesarean deliveries. ${ }^{32}$ Goswami et al had $43.5 \%$ cesarean deliveries. ${ }^{33} \mathrm{~A}$ contrast observation was that vaginal delivery rate was $78 \%$ in spite of high risk conditions and various complications in Devineni et al. ${ }^{34}$

A maternal death in a gravid 5 had overt diabetes and hypertension and previous two abortions and 2 cesarean section presented with rupture uterus and shock was from private sector and reached in half an hour. Cesarean hysterectomy and five units of Packed RBCs were transfused, and maternal death could not be averted. Goswami et al reported hypertensive disorders and their complications as a leading cause of maternal mortality. ${ }^{33}$ There were 4 near misses which were due to severe preeclampsia and HELLP syndrome. Ten cases needed blood transfusion. 12 cases were given Magsulf regime for impending eclampsia/ eclampsia/ severe 
preeclampsia. There were 2 cases of posterior reversible encephalopathy syndrome. All the 7 mothers who needed ventilator support not related to anesthesia were from private sector. There were 2 cases of papilledema and 2 patient needed plasmapheresis for acute renal failure. Goswami et al reported $8.02 \%$ needed obstetric ICU admissions. ${ }^{33}$ Shelat et al concluded that emergency obstetric referrals were exposed to highest risk of maternal and perinatal complications. ${ }^{35}$

Out of 141 babies, there were 121 survivors (21 and 90 in public and private) sector respectively. NICU admissions were statistically significant in private sector referrals (pvalue 0.001 ) due to preterm referrals and very low-birth weight babies. As the public sector referral babies were near term, shorter NICU stay ( $<6$ days) $83 \%$ making $p$ value statistically significant (p-value 0.007 ). Need to resuscitate by ventilator was $71 \%$ in private sector and $50 \%$ in public sector referrals ( $\mathrm{p}$-value 0.020). Mean hospital stay in private sector referrals was 10.17 days and it was 7.62 days in government referrals. Survival rate of babies in present study was $84.5 \%$ due to the stateof-the-art neonatal care facilities. $77.3 \%$ were low birth weight babies of less than $2500 \mathrm{~g}$ in contrast to $56 \%$ LBW babies in Rathi et al. $51 \%$ were male babies and $48 \%$ female 24 neonates ( 2 born to public and 22 born to private) succumbed to prematurity, respiratory distress, hypoxic ischemic encephalopathy and sepsis. The perinatal mortality rate is 14.63 . There were 11 neonatal deaths in babies of multifetal gestation. In Devineni et al, total number of live births were $73(78.5 \%)$ among which $28(30 \%)$ required neonatal admission and $5(5.3 \%)$ had early neonatal death. ${ }^{34}$ As in Khatoon A, et al, $26.5 \%$ neonates were transferred to NICU and perinatal mortality was $41 \% .^{36}$

\section{CONCLUSION}

This study concluded that wide spectrum of complicated obstetric cases were referred to this hospital. Specific guidelines for "whom to refer", "how to refer" "when to refer" and "where to refer" would be helpful in making timely referral. Improved competencies of staff for management of labour will improve patient management and reduce unjustified referrals. Treatment during transit in referrals should be stressed. More stringent documentation in the referral slips and more coordination between the referral unit and the higher centers with simultaneously developing and instituting obstetric referral guidelines, monitoring of referrals will escalate the benefit in developing a strong health system. In India.

\section{ACKNOWLEDGMENTS}

Authors would like to thank Dr. K. T. Shenoy, Retired Professor and Clinical Epidemiologist Medical College Trivandrum and Mr. Sony Simon, Statistician of Travancore Medical College and all the participants for their help and assistance.
Funding: No funding sources

Conflict of interest: None declared

Ethical approval: The study was approved by the Institutional Ethics Committee

\section{REFERENCES}

1. WHO recommendations on antenatal care for a positive pregnancy experience. 2016. Available at: http://apps.who.int/iris/bitstream/handle/10665/2507 96/9789241549912-eng.pdf;jsessionid =18034EA81EF0025D671F7767629BFE5A?sequen ce $=1$.

2. Jahn A, De Brouwere V. Referral in pregnancy and childbirth: concepts and strategies. In Vincent De Brouwere and Wim Van Lerberghe. Antwerp: ITG Press; 2001:229-246. (Studies in Health Services Organisation and Policy; 17) Available at: http://www.jsieurope.org/safem/collect/safem/pdf/s2 940e/s2940e.pdf.

3. World Health Organisation, UNICEF, UNFPA, World Bank, UN Population Division. Trends in maternal mortality: 1990 to 2013. Estimates by WHO, UNICEF, UNFPA, the World Bank and the United Nations Population Division. Geneva: World Health Organisation; 2014.

4. Thaddeus S, Maine D. Too far to walk: maternal mortality in context. Soc Sci Med. 1994;38(8):1091110.

5. Lawn JE, Lee AC, Kinney M, Sibley L, Carlo WA, Paul VK, et al. Two million intrapartum-related stillbirths and neonatal deaths: Where, why, and what can be done? Int $\mathbf{J}$ Gynecol Obstet. 2009;107(Supplement):S5-19.

6. Bindal J, Agrawal N, Sharma DC. Over view of referred obstetric patients and their outcome in tertiary case Hospital. JMSCR. May 2017;5(5).

7. Shailja S, Singh M. National health policy 2017. Can it lead to achievement of sustainable developmentgoals?. Available at: https://www.researchgate.net/profile/Mitasha_Singh/ publication/322287585_National_health_policy_201 7_Can_it_lead_to_achievement_of_sustainable_deve lopment_goals/links/5a505 0140f7e9bbc10538ef7/National-health-policy-

2017Can-it-lead-to-achievement-ofsustainabledevelopment-goals.pdf.

8. International Institute for Population Sciences, Macro International. National family health survey (NFHS-3), 2005-2006: India: Mumbai: IIPS; 2007;1.

9. Chandramouli C. Census of India 2011: Provisional population totals: Paper 1 of 2011. India: Series 1. New Delhi: Office of the Registrar General and Census Commissioner, India; 2011.

10. National Rural Health Mission (2013) Ministry of Health and Family welfare Government of India, New Delhi. Available at: http://nrhm.gov.in.

11. Chaturvedi S, Randive B, Diwan V, De Costa A. Quality of obstetric referral services in India's JSY cash transfer programme for institutional births: a 
study from Madhya Pradesh province. PloS One. 2014;9(5):e96773.

12. Morsheda B, Shamsun N, Hashima EN. Assessing the MANOSHI referral system addressing delays in seeking emergency obstetric care in Dhaka's slums. MANOSHI working paper series Manoshi-WP10:136 published by ICDDR, B, BRAC. 2010;10.

13. Vinayak NM, Panditrao SK, Ramkrishna MA. Critical study of referrals in Obstetric Emergencies. J Obstet Gynaecol India. 2004;54:258-9.

14. Wahane AR, Koranna PS. An analysis of maternal deaths in a tertiary care centre. J Evol Med Dent Sci. 2014;3:8646-52.

15. Ohn HT, Patrick DC, Zaw W, Mary K, Hnin YK, Herni B. Inter-hospital emergency obstetric referrals to the labour ward of RIPAS Hospital Brunei. Int Med J. 2011;7(1):22-33.

16. Sheikh A, Dunphy J, Humphries C, MacArthur C, Manaseki-Holland S. Maternity handover in Kerala: a cross sectional study. Int J Community Med Public Health. 2018;5:3760-6.

17. Sodani PR, Sharma K. Training needs assessment of public health programmes in maternal and neonatal care. Indian J Mat Child Heal. 2011;13(4):1-8.

18. Pembe AB, Carlstedt A, Urassa D, Lindmark G, Nyström L, Darj E. Effectiveness of maternal referral system in a rural setting: a case study from Rufiji district, Tanzania. BMC Heal Ser Res. 2010;10:326.

19. Gupta M, Mavalankar D, Trivedi P. A study of referral system for EmOC in Gujarat. PhD thesis, IIM Ahmedabad. 2009. Available at: http://www.iimahd.ernet.in/publications/data/200906-02Gupta.pdf.

20. Maitra K, Singh KK, Sekhar CC, Saxena BN. A multicentre collaborative study of the care of mothers and infants with a comprehensive $\mathrm{MCH}$ care package utilizing high risk approach strategy at primary health centres: summary, conclusions and recommendations. Indian Pediatr. 1995;32(1):67-72.

21. Barua A, Waghmare $\mathrm{R}$, Venkiteswaran $\mathrm{S}$. Implementing reproductive and child health services in rural Maharashtra, India: A pragmatic approach. Reprod Heal Matters. 2003;11(21):140-9.

22. Akbari A, Mayhew A, Al-Alawi MA, Grimshaw J, Winkens R, Glidewell E, et al. Interventions to improve outpatient referrals from primary care to secondary care. Cochrane Database Syst Rev. 2008;4:CD005471.

23. UNFPA. Concurrent assessment of Janani Suraksha Yojana (JSY) in selected states: Bihar, Madhya Pradesh, Orissa, Rajasthan, Uttar Pradesh. New Delhi: UNFPA- India; 2011.

24. Alehagen SA, Finnstrom O, Hermansson GV, Somasundaram KV, Bangal VB, Patil A, et al.
Nurse-based antenatal and child health care in rural India, implementation and effects-an Indian-Swedish collaboration. Rural Remote Heal. 2012;12(3):2140.

25. Rathi C, Gajria K, Soni N. Review of referred obstetric cases-maternal and perinatal outcome. Bombay Hosp J. 2010:52:52-6.

26. Patel HC, Singh BB, Moitra M, Kantharia SL. Obstetric referrals: scenario at a primary health centre in Gujarat. Natl J Community Med. 2012;3:711-4.

27. Agarwal N, Singla R, Dhaliwal L, Suri V. Audit of emergency obstetric referrals-a pilot study from tertiary care centre of North India. Bangla J Obstet Gynaecol. 2015;30:25-9.

28. Hitesh J. Perceptions and constraints of pregnancy related referrals in rural Rajasthan. J Fam Welfare. 1996;42(1):24-9.

29. Kaul V, Bagga R, Jain V, Gopalan S. The impact of primary postpartum hemorrhage in "near-miss" morbidity and mortality in a tertiary care hospital in North India. Indian J Med Sci. 2006;60(6):233-40.

30. Narsaria K, Mukhopadhaya P, Kyal A, Agarwal K, Agarwal A, Sanghi S. Study of obstetric referrals one year experience at a tertiary care centre in West Bengal HECS. Int $\mathbf{J}$ Com Health Med Res. 2017;3(3):32-6.

31. Potter JE, Berquó E, Perpétuo IH, Leal OF, Hopkins $\mathrm{K}$, Souza MR, et al. Unwanted caesarean sections among public and private patients in Brazil: prospective study. BMJ. 2001;323(7322):1155-8.

32. Ambreen A, Khurshid S, Khurshid M, Khan F, Intisar A. Obstetric outcome of cases referred to a tertiary care hospital after trial of labour. Annals. 2012;18(1):71-80.

33. Goswami D, Makhija A. A study of high risk obstetric referrals to a tertiary care hospital in Garhwal, Uttarakhand. IJSR. 2015;4(10):1091-3.

34. Devineni K, Sodumu N. A study of spectrum of referral pattern at a tertiary teaching hospital towards better obstetric care. IAIM. 2016; 3(8): 193-198.

35. Shelat NR, Mehta AA, Jassawala MJ. Emergency, referred, and late admission for Delivery. J Obstet Gynecol Ind.1984;34:676-83.

36. Khatoon A, Hasny SF, Irshad S, Ansari J. An audit of obstetrics referrals to Abbasi Shaheed Hospital. Pak J Surg. 2011;27(4):304-8.

Cite this article as: Shenoy HT, Shenoy S. Interhospital obstetric referrals: public versus private sector to a tertiary care teaching hospital in South Kerala, India. Int J Reprod Contracept Obstet Gynecol 2019;8:86-93. 